\title{
Advanced Clinical Medicine Requires Advanced Clinical Ethics
}

\author{
Thor Willy Ruud Hansen
}

Department of Neonatology, Women's and Children's Division and Clinical Ethics Committee, Oslo University Hospital HC - Rikshospitalet, and Institute of Clinical Medicine, Faculty of Medicine, University of Oslo, Oslo, Norway

\section{Key Words}

Clinical ethics $\cdot$ Medical advances $\cdot$ Innovation .

Technological medicine

\begin{abstract}
Many advances have occurred in clinical medicine in the last decades. Solid organ transplants, corrective surgery for congenital malformations, improved cytostatic regimes for children with cancer, and respiratory care for premature infants are but a few examples of the changing face of medical practice. Such changes have added years to life. But along the way many patients have paid a price, both in terms of loss of life and of added suffering. Even today, some survivors are faced with a life of impairment and suffering. Follow-up studies of extremely low-birth-weight infants show that the smallest infants have a high rate of severe sequelae. Some argue that such suffering should be sufficient reason to make us desist from further attempts to advance the frontiers of therapy. This paper seeks to reflect on the character of advanced medicine and on how we relate to patients and their kin in our quest for further improvements in therapy. The price for continued advances will inevitably be paid by some patients who will not profit from them. Therefore, patients who are asked to participate in such a quest must receive honest and transparent information, including a discussion about where and how they would draw the limits.
\end{abstract}

Clinical competency is a core concept in advanced medicine, but a caring comportment also demands that our relationship to the patient be characterized by honesty, integrity, and decency. In dialogue with parents, finding the right balance between parental exercise of autonomy and safeguarding the best interest of the child remains a challenge.

Copyright $\odot 2011$ S. Karger AG, Basel

\section{Glimpses from the Recent Past}

On August 9, 1963, Patrick Bouvier Kennedy died in Boston, Mass., USA, reportedly from 'hyaline membrane disease' [1]. He was 2 days old and the youngest son of Jaqueline Bouvier and John Fitzgerald Kennedy. His delivery had been by cesarean section at $34 \frac{1}{2}$ weeks of gestation, and his birth weight was $2,112 \mathrm{~g}$. Ventilatory support of newborn babies was in its infancy and apparently was not attempted for Patrick [1]. Thus, less than 50 years ago the newborn son of arguably the most powerful man in the world died because the medical profession did not have the tools to help him. Today, survival of such an infant would be the expected routine, the treatment would not be seen as particularly challenging, and death would be a highly unusual outcome in countries with well-developed medical care systems.

\section{KARGER}

Fax +4161306 1234 E-Mail karger@karger.ch www.karger.com
(C) 2011 S. Karger AG, Basel

1661-7800/12/1011-0008\$38.00/0

Accessible online at:

www.karger.com/neo
Thor Willy Ruud Hansen, MD, PhD, MHA

Nyfødtavdelingen, Kvinne- og Barneklinikken

Oslo Universitetssykehus HF - Rikshospitalet

NO-0027 Oslo (Norway)

Tel. +47 2307 4573, E-Mail t.w.r.hansen@ medisin.uio.no 
Although mechanical ventilation of newborn infants had been described in conjunction with surgery, and ventilators adapted for newborns were by the early $1960 \mathrm{~s}$ in use at the Karolinska Hospital [2], at the time of Patrick Kennedy's death they were still far from routinely used. Early neonatal ventilators were simple and primitive, at least when looked at from a 21st century perspective. Survival was sometimes achieved at the cost of chronic and disabling lung disease. Today we have ventilators which may be controlled by infants as small as $500 \mathrm{~g}$ of weight.

The first experience with surfactant for treatment of respiratory distress syndrome was published in 1980 [3]. Although in many ways deserving of the label 'miracle drug', surfactant administration was nevertheless in the early trials associated with complications such as pneumothorax and pulmonary hemorrhage. Today surfactant therapy is standard of care and is given to thousands of infants each year, for the most part with excellent outcome and few and limited side effects.

\section{Medical Progress and Its Price}

Advanced clinical medicine as we know it today is a result of progress in many areas. There have been some 'quantum leaps', but there have also been many smaller steps. One example of such smaller, but still very important steps is the development of plastic materials which enables us to provide nutrition and a multitude of drugs through small-bore intravenous needles and catheters in even the tiniest of infants.

For almost all progress a price has been paid. For some, this price was personal and/or humanitarian. Many paid the price of death 'on the learning curve' of the professionals applying a new treatment. Others have paid the price of increased suffering. When treatment regimes were intensified to improve the survival of childhood cancers, those who might have survived with less intensive therapy paid a price in the form of more suffering due to side effects. They did not benefit from this suffering, but they did help those who would not have survived with the less intense and demanding regimes. With intensification of therapy, such suffering was predictable. However, there have also been unexpected side effects, such as progressive deterioration of CNS function in children given CNS irradiation for cancer at a young age [4].

Progress may also have a price in financial terms. Individuals who survive, but remain disabled by their illness, may experience a permanently reduced ability to work and consequently a reduced income. In countries with self-paying health care systems the expense of a new treatment may bring the individual close to ruin, with a long-term negative economic and social impact on the whole family. For society, the high costs of new therapies contribute significantly to the rapidly escalating costs of health care delivery. Our reluctance to say 'no', even when that might have been the humane answer, fuels the spiral [5]. Increased survival, but with disability, will add to the costs incurred by society to take care of its disabled. Both the individual and society need to consider the concept of alternative costs [6]: 'What would the same amount of money have bought if invested differently?' An individual who spent the remainder of his/her life savings on a futile new cancer therapy might instead have made that trip they had always dreamt of, or put the money into a college fund for their grandchildren, or used the money to help third-world orphans. A society which spends a significant part of its health expenditures on frequently futile intensive care for people at the end of their life cycle [7] might instead invest those funds in preventive and curative health care for poor children.

\section{Seductive Success}

There is little doubt that modern medicine is in many ways a success story. Surely none of us want a return to the medicine of older times, when physicians had limited tools to influence the course of illness in their patients. In fact, some of these tools were more likely to harm than heal. But it may be worthwhile to reflect on how the mind-set of health workers has changed [8]. Our understanding of disease is based on the study of populations, and the concept of evidence-based medicine assumes that the real evidence is found in the study and comparison of large groups of people. The individual is assumed to have the characteristics which identify the group. This means that the question of who the individual is has become less interesting and less important. Some have suggested that one of the reasons why practitioners of alternative medicine enjoy success is that they give their clients time and a feeling of being important.

Lantos [8] has provocatively suggested that: 'When disease cannot be cured, or when suffering can no longer be relieved, doctors are no longer sure what to do or whether they still have a role to play.' We are trained to fix, and when we cannot fix we withdraw from the stage. In this light we can understand why physicians and nurses who have chosen to work with cancer, nevertheless, feel 
uncomfortable when confronted with the impending demise of their patients [9]. And perhaps we can also begin to understand why an increasing number of elderly patients end their lives in an ICU with full 'life' support, rather than in their homes or a nursing home bed [10].

\section{Approaches to Medical Ethics}

Ethics in medicine can be approached from several angles. The principle of benevolence translates into helping, curing, comforting, and palliating. Approached from the other side, the principle of nonmaleficence directs us to avoid causing harm. Justice must also be a part of clinical ethics and is embodied in article 25 of the Universal Declaration of Human Rights [11] as far as it applies to the right to health care. The right to health care is even more specifically expressed in article 24 of the UN Convention on the Rights of the Child [12]. However, it can be argued that justice in medical ethics cannot be limited to a right to health care, but must and should also encompass the equality of such rights for every citizen. Such equality of access is, unfortunately, not the prevailing norm around the world, and cannot be taken for granted even in countries which subscribe to this ideal.

The law may play an even larger role in medical ethics in countries which have passed laws regulating the rights of patients. Thus, in Norway, the Act on Patients' Rights [13] grants patients the right (1) to choose their hospital (with certain limitations); (2) to contribute to and make decisions regarding their own treatment, including consenting to or refusing to consent to a plan for treatment; (3) to receive an 'individual plan' for therapy, and (4) to receive information about the disease as well as the plans for investigations and therapy.

\section{Rights Imply Challenges}

With the advent of laws which describe patients as having rights, democracy may be said to have entered health care. The modern patient can no longer be expected to quietly accept a doctor's decision, but has become an active, informed, and at times quite demanding participant. Sick people today ask more questions. They want more details, they may seek 2 nd and 3rd opinions, they recognize that our knowledge is limited, and consequently they may no longer accept the doctor's word as the final truth.
There are certain prerequisites for user involvement. Thus, a patient's (or proxy's) participation in decision making is meaningful only if the patient is able or competent to understand, to reason, and to decide. In pediatric health care age and maturity are key elements to consider - when should children be involved in decision making? The Norwegian Act on Patients' Rights states that from the age of 12 years a child has an increasing right to be heard, and from the age of 16 years a youngster's opinion will override that of his/her parents [13].

Cognitive ability and cognitive changes may impact comprehension. Thus, a person who is immature, developmentally delayed, or is suffering from dementia may neither be capable of understanding an explanation which is offered, nor the implications of decisions which must be made. Although parents or legal guardians need to be involved in such cases, they may have their own agendas which may not necessarily coincide with the best interests of the patient [14]. Thus, one of the pitfalls in neonatal and pediatric medicine is the assumption that parents always recognize their child's best interest and act accordingly [15-18]. It may be helpful to keep in mind that the reason why we have child protection laws is that parents occasionally fall short of the standard society demands of those who care for children. If the experienced doctor or nurse who cares for a child admits a sense of unease when confronted with the demands or behavior of the parents, a discussion within the team, an assessment by social services, or involvement of child protection services may all serve to clarify the situation.

Understanding is a basic prerequisite for evaluating and deciding. This means that information must be conveyed in a way that can be understood by the patient or his/her guardian $[15,19]$. The ability to explain complex biological and medical issues is unequally distributed among medical staff. Sometimes the inability to do this clearly may be due to a lack of training. However, we must recognize that using difficult words may also be a convenient mask for our own insecurity.

However, even when both the will and the ability to communicate are present, these are obstacles to be overcome. Examples of such obstacles are a disparity in intellectual and educational background, differences in culture, differences in thinking about the origins of health and disease, and language barriers [15]. The latter may be particularly risky, because we can easily fall into the trap of assuming that if the words have been translated, the meaning has also been communicated. However, the concepts behind the words may be worlds apart. 


\section{Risks in Patient Involvement}

Involving the patient (or proxy) in important decisions, with the intention to emancipate him or her, may change the patient-doctor relationship in unforeseen ways. We may be tempted to deny responsibility for unfortunate results: 'You made the decision - you are responsible for the outcome.' We may cover up or avoid difficult ethical dilemmas by deferring uncritically to the patient's wishes $[5,20]$. Another potential trap is shirking responsibility for resource allocation by carrying out expensive, nonindicated exams and studies just because 'the patient asked for it'.

Depending on the legal environment there may be limitations in patient autonomy. In the Norwegian Act on Patients' Rights the right of a competent adult to abstain from treatment is extensive. However, there are significant limits in the rights of parents to abstain from treatment of their children [13]. In fact, if the proposed treatment is clearly in the child's best interest, parental objections can and should be overridden. The right to a positive choice' of a given treatment is limited by the lack of documentation of the effect of that treatment ('evidence base'). Further, the proposed treatment must conform to national requirements for 'sound professional practice' and must have an 'acceptable cost/benefit ratio' [13], although no specific interpretation of the latter has been advanced. As regards autonomy, Paris [20] has argued that taking that concept to mean that doctors should do whatever the patient (or proxy) requests is a misunderstanding based on a confusion of research and bedside ethics.

\section{Advanced Ethics in Advanced Clinical Medicine}

In advanced clinical medicine some of our therapies are distinctly burdensome. On the individual front, how do we handle the situation when our patients no longer want a part of our offerings? There is also a trend for our therapies to become more expensive. What do we do when our budgets are limited, as they often are in publicly financed health care, when insurers refuse to approve the treatment, or when the individual is unable to foot the bill?

When resources are limited we must assume responsibility for prioritizing. This means that we may not be able to do everything for everybody. Sometimes we may have to look parents or patients in the eyes and say 'no' [5]. In spite of our individual or institutional ambitions, we must perhaps ask if everything that is offered at 'St. Elsewhere' should necessarily be standard of care at our hospital. Is the result of an intervention worth the cost? Which effects does it have on survival at what price? Which effects does it have on quality-of-life at what price?

This may involve greater attention to the concept of 'alternative cost' [6]. Do we get more out of a given amount of money by investing it in high-cost care of a small group of patients with marginal effect on survival and health? Or might we get 'more' out of the same amount by investing it in time, attention, and dialogue with patients and families in existential crises? Or should we perhaps invest the same amount in better palliative care and symptom relief for those patients for whom we have no cure?

When resources are limited, equity in distribution becomes important. This is particularly true in countries with nationally funded health care. We must reflect well and it must be transparent how and why we make our choices. Perhaps it would be helpful if in our organizations we had mechanisms to assist in these decisions. Clinical ethics committees would appear to be a possible venue for such a task, but in our own clinical ethics committee such issues have been raised only exceptionally. However, in Norway the National Council for Quality and Prioritization was recently given the task of addressing such issues on a national level.

\section{Research and Innovation in Advanced Medicine}

Advanced medicine is often tied to research. This requires that we scrutinize our motives for any hidden agendas. Are we primarily looking for more recruits for our study, or are we truly focused on healing our patients? When are we scientists and when are we doctors? Is our research conducive to health or (mostly) conducive to our careers?

Advanced medicine is born through innovation. Somebody dares to go where nobody has gone before, and patients participate in this, often perilous, journey. Medical history contains many examples of innovation which did not end well for the first patients. Innovative medicine requires carefully thought out strategies for coping with failure. Innovators are likely to be of a competitive nature and may need to work on the way in which they handle a loss. For the individual patient or proxy it is necessary to explore their own expectations and understanding before embarking on the new course. What are their own limits? What support and help from us would the 
patient or proxy need if we decided to withdraw or limit active therapy? When innovation 'pushes the envelope', we need to reflect in advance on where to draw the line.

\section{'Practice Makes Perfect...'}

Few would disagree that in order to master advanced clinical medicine you must practice it. This is reflected in rules for specialist and subspecialist training, which specify years of training, number of supervised procedures, courses attended, and exams passed. The practice of clinical ethics also requires knowledge and training. This includes knowing the basic theory of medical ethics, knowledge of the law and of patients' rights, knowledge about human psychology and emotions, as well as training in communication and sensitivity. Self-knowledge and ability to reflect on who and how you are are prerequisites, as is the ability to control your own emotions when face-to-face with the suffering of others. Most of this can be learned by hard, dedicated work!

\section{Core Values in Advanced Health Care}

The Parliamentary Report 26 (1999-2000) 'On Values for Norwegian Health Services' [21] states that: 'The encounter between patient and health worker is at the core of health care delivery. This encounter must be based on respect and on love for your neighbor.' The Norwegian Act on Health Personnel Paragraph 4 states that the treatment we offer must be (1) in accordance with sound professional practice and (2) considerate/caring [22]. Although these examples are drawn from Norwegian official documents, they are universal and apply to healthcare everywhere. Thus, while clinical competency is at the core of advanced medicine, it cannot on its own guarantee humane care. In the end, the practice of advanced clinical medicine also demands of the health care worker some personal attributes that transcend medicine. Such attributes include honesty, integrity, and decency combined with respect for your patient as a fellow human being.

\section{References}

1 Goldsmith JP, Karotkin EH: Introduction to assisted ventilation; in Goldsmith JP, Karotkin EH (eds): Assisted Ventilation of the Neonate, ed 4. Philadelphia, Saunders, 2003, pp $1-14$.

-2 Swensson A: Management of the Engstrom respirator in early infancy. Arch Dis Child 1962;37:156-158.

-3 Fujiwara T, Maeta H, Chida S, Morita T, Watabe Y, Abe T: Artificial surfactant therapy in hyaline-membrane disease. Lancet 1980;1: 55-59.

4 Duffner PK, Cohen ME, Thomas PR, Lansky SB: The long-term effects of cranial irradiation on the central nervous system. Cancer 1985;56:1841-1846.

$\checkmark 5$ Thurow LC: Learning to say 'no'. N Engl J Med 1984;311:1569-1572.

6 American Thoracic Society: Understanding costs and cost-effectiveness in critical care: report from the second American Thoracic Society workshop on outcomes research. Am J Respir Crit Care Med 2002;165:540-550.

7 Levine SK, Sachs GA, Jin L, Meltzer D: A prognostic model for 1-year mortality in older adults after hospital discharge. Am J Med 2007;120:455-460.
8 Lantos JD: Do We Still Need Doctors? New York, Routledge, 1997.

9 Aakre M: Hvorfor er det så vanskelig å sitte ned? Omsorg 1998;15:50-54.

10 Lantos JD, Mokalla M, Meadow W: Resource allocation in neonatal and medical ICUs: epidemiology and rationing at the extremes of life. Am J Respir Crit Care Med 1997;156: 185-189.

11 United Nations: Universal Declaration of Human Rights, 1948. http://www.un.org/en/ documents/udhr/index.shtml.

12 United Nations: Convention on the Rights of the Child, 1989. http://www2.ohchr.org/ english/law/crc.htm.

13 LOV 1999-07-02 nr 63: Lov om pasientrettigheter. http://www.lovdata.no/all/ hl-19990702-063.html.

14 Ot prp nr 12 (1998-99) Lov om pasientrettigheter. Oslo, Det kongelige Sosial- og Helsedepartement, 1999.

15 Schroeder J: Ethical issues for parents of extremely premature infants. J Paediatr Child Health 2008;44:302-304.

16 American Academy of Pediatrics: Noninitiation or withdrawal of intensive care for high risk newborns. Pediatrics 2007;119:401-403.
17 Paris JJ, Schreiber MD, Morland MP: Parental refusal of medical treatment for a newborn. Theor Med Bioethics 2007;28:427441.

18 Paris JJ, Graham N, Schreiber MD, Goodwin M: Approaches to end-of-life decision-making in the NICU: insights from Dostoevsky's The Grand Inquisitor. J Perinatol 2006;26: 389-391.

19 Richards N: Life or death decisions in the NICU. J Perinatol 2006;26:248-251.

$>20$ Paris JJ: Autonomy does not confer sovereignty on the patient: a commentary on the Golubchuk case. Am J Bioethics 2010;10:5474.

21 St. meld. nr. 26 (1999-2000) Om verdiar for den norske helsetenesta. http://www.regjeringen.no/nb/dep/hod/dok/regpubl/stmeld/19992000/stmeld-nr-26-1999-2000-. html?id=192850.

22 LOV 1999-07-02 nr 64: Lov om helsepersonell m.v. (helsepersonelloven). http://www. lovdata.no/all/hl-19990702-064.html. 